\title{
PENERAPAN MODEL PEMBELAJARAN KOOPERATIF TIPE STUDENT TEAMS ACHIEVEMENT DIVISION UNTUK MENINGKATKAN HASIL BELAJAR MATEMATIKA SISWA

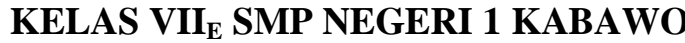

\author{
Nurzayana $^{\text {I) }}$,Hafiludin Samparadja ${ }^{2)}$, Kadir Tiya ${ }^{3)}$ \\ ${ }^{1)}$ Alumni Jurusan Pendidikan Matematika, ${ }^{2,3)}$ Dosen Jurusan Pendidikan Matematika \\ FKIP Universitas Halu Oleo: email: nur.zayana@yahoo.com; hafiludin79@yahoo.com; \\ kadir.tiya@yahoo.com
}

\begin{abstract}
Abstrak
Penelitian ini bertujuan untuk meningkatkan hasil belajar matematika siswa kelas VII $_{\mathrm{E}}$ SMP Negeri 1 Kabawo melalui penerapan model pembelajaran kooperatif tipe STAD. Subjek penelitian ini adalah guru dan siswa kelas $\mathrm{VII}_{\mathrm{E}}$ SMP Negeri 1 Kabawo yang terdaftar pada semester ganjil tahun ajaran 2017/2018 dengan jumlah siswa sebanyak 25 orang. Jenis penelitian ini adalah penelitian tindakan kelas. Data dalam penelitian ini adalah data kualitatif dan data kuantitatif. Data kualitatif diambil dengan menggunakan lembar observasi, sedangkan data kuantitatif diperoleh melalui tes siklus. Berdasarkan hasil penelitian, terjadi peningkatan hasil belajar siswa dari tes awal ke siklus I ke siklus II maupun ke siklus III. Hal ini dapat dilihat dari nilai tes awal, siswa yang memperoleh nilai minimal 71 sebanyak 40\% meningkat siklus I menjadi 64\% siswa yang mencapai KKM, pada siklus II meningkat pula menjadi $76 \%$ dan pada siklus III mengalami peningkatan lagi sebanyak $92 \%$ siswa telah mencapai standar KKM.
\end{abstract}

Kata Kunci: model pembelajaran kooperatif, hasil belajar matematika

\section{APPLICATION OF COOPERATIVE LEARNING MODELS TYPE STUDENT TEAMS ACHIEVEMENT DIVISIONTO IMPROVE STUDENT MATH LEARNING RESULTS AT CLASS VII OF SMP NEGERI 1 KABAWO}

\begin{abstract}
This study aims to improve students' mathematics learning outcomes through the application of STAD type cooperative learning model at class $\mathrm{VII}_{\mathrm{E}}$ of SMP Negeri 1 Kabawo. The subjects of this study were the teacher and the students at class $\mathrm{VII}_{\mathrm{E}}$ of SMP Negeri 1 Kabawo who enrolled in the first semester of the academic years 2017/2018 with a total of 25 students. This type of research is classroom action research (CAR). There were two types of data in this study namely qualitative and quantitative data. Qualitative data were taken by using observation sheet, while the quantitative data was obtained through the cycle test. Based on the results of research, there is an increase in student learning outcomes from the initial test to the first cycle to the second cycle as well as the third cycle. This can be seen from the initial test score, the students who get a minimum score of 71 as many as $40 \%$ increased in the first cycle $64 \%$ of students who reached KKM, in the second cycle also increased $76 \%$ and in the third cycle has increased again as many as $92 \%$ of students have reached KKM standards.
\end{abstract}

Keywords: cooperative learning model, mathematics learning outcomes 


\section{Pendahuluan}

Pendidikan merupakan kunci untuk mempercepat pencapaian tujuan pembangunan nasional, oleh karena itu sektor pendidikan selalu mendapat perhatian yang besar dari pemerintah. Untuk mewujudkan hal tersebut para guru diberikan kesempatan untuk mengikuti pelatihan-pelatihan baik secara lokal maupun regional yang berhubungan dengan pelaksanaan pembelajaran. Pengadaan pelatihan bagi guru dimaksudkan untuk meningkatkan penguasaan materi ajar dan keterampilan mengajar.

Matematika merupakan salah satu pelajaran yang diajarkan pada jenjang pendidikan dasar, pendidikan menengah maupun pendidikan tinggi. Matematika adalah sabagai salah satu cabang ilmu yang dinilai dapat memberikan kontribusi positif dalam mengembangkan ilmu pengetahuan dan teknologi sehingga menjadi sangat penting dalam upaya peningkatan mutu pendidikan.

Selama ini matematika bagi sebagian besar siswa adalah pelajaran yang sangat membosankan karena selalu dipenuhi dengan rumus-rumus yang rumit. Tak heran jika nilai matematika rata-rata lebih rendah bila dibandingkan dengan mata pelajaran lainnya, walaupun dalam proses pembelajaran di kelas, telah banyak pendekatan-pendekatan dalam mengajar yang diterapkan oleh guru, namun belum mencapai hasil yang maksimal, baik ulangan harian maupun ulangan semester (Rahma Fitri dkk, 2014:19).

Berdasarkan hasil observasi awal di SMP Negeri 1 Kabawo, pada tanggal 24 Agustus 2017, ditemukan kenyataan bahwa proses pembelajaran matematika yang terjadi di kelas secara umum adalah proses belajar mengajar cenderung metode ceramah atau masih berpusat pada guru, siswa cerita saat guru mengajar, tidak ada kerjasama antar siswa, siswa tidak dikelompokkan dalam belajar, dan kurangnya minat siswa untuk belajar. Hal ini siswa kurang aktif dalam kegiatan pembelajaran, akibatnya matematika dianggap sulit serta tidak dipahami oleh siswa sehingga berimplikasi pada rendahnya hasil belajar matematika yang diperoleh siswa. Penelitian ini bertujuan untuk meningkatkan hasil belajar matematika siswa kelas VIIE SMP Negeri 1 Kabawo melalui penerapan model pembelajaran kooperatif tipe STAD.
Berdasarkan data yang diperoleh dari guru matematika kelas VII ditemukan juga bahwa data hasil belajar matematika siswa terlihat sebaran rendahnya nilai rata-rata pada ulangan harian semester I tahun ajaran 2017/2018 yang tidak mencapai Kriteria Ketuntasan Minimal (KKM) yang ditetapkan di sekolah yakni 71 atau belum mencapai minimal 80\% (sumber: KKM mata pelajaran matematika di sekolah SMP Negeri 1 Kabawo). Nilai ratarata ulangan harian untuk kelas $\mathrm{VII}_{\mathrm{A}}=69,77$, kelas $\mathrm{VII}_{\mathrm{B}}=69,96$, kelas $\mathrm{VII}_{\mathrm{C}}=68,90$, kelas $\mathrm{VII}_{\mathrm{D}}=70,45$, kelas $\mathrm{VII}_{\mathrm{E}}=66,52$, kelas $\mathrm{VII}_{\mathrm{F}}=$ 68,45 , dan kelas $\mathrm{VII}_{\mathrm{G}}=67,95$. Berdasarkan uraian diatas, perlu diupayakan model pembelajaran yang efektif dan efisien, sebagai alternatif untuk meningkatkan aktivitas belajar sehingga diharapkan dapat meningkatkan hasil belajar siswa.

Matematika sebagai ilmu mengenai struktur dan hubungan-hubungannya memberikan simbol. Menurut Bruner (Depdiknas, 2009:7), mengemukakan bahwa belajar matematika adalah belajar tentang konsep-konsep dan struktur matematika yang terdapat dalam materi yang dipelajari serta mencari hubungan antara konsep-konsep dan struktur matematika. Matematika merupakan disiplin ilmu yang mempunyai karakteristik khusus bila dibandingkan dengan disiplin ilmu yang lain. Menurut Sumardiono (Hairani, 2010: 8), matematika memiliki karakter sebagai berikut; (1) memiliki objek kajian abstrak, (2) Bertumpuh pada kesepakatan, (3) Berpola pikir deduktif, (4) Kosinsten dalam sistemnya, (5) Memiliki symbol, (6) Memperhatikan semesta pembicaraan.

Pembelajaran matematika merupakan proses dimana siswa secara aktif mengkonstruksi pengetahuan matematika. Pengetahuan matematika akan lebih baik jika siswa mampu mengkontruksi melalui pengalaman yang telah mereka miliki sebelumnya. Untuk itu, keterlibatan siswa secara aktif sangat penting dalam kegiatan pembelajaran. Dalam hal ini pembelajaran matematika merupakan pembentukan pola pikir dalam penalaran suatu hubungan antara suatu konsep dengan konsep yang lainnya (Rahma Fitri dkk, 2014: 18).

Belajar dan mengajar merupakan dua konsep yang berbeda dalam pembelajaran tetapi dua konsep tersebut tidak dapat dipisahkan satu 
sama lainnya. Dengan kata lain, belajar dan mengajar merupakan dua konsep yang erat kaitannya. Belajar menunjuk apa yang harus dilakukan seseorang sebagai subyek yang menerima pelajaran (sasaran didik), sedangkan mengajar menunjuk pada apa yang harus dilakukan oleh guru sebagai pengajar. Dua konsep tersebut menjadi terpadu dalam satu kegiatan pembelajaran, manakala terjadi interaksi antara guru dan siswa, atau siswa dan siswa pada saat pembelajaran berlangsung. Interaksi guru dan siswa memegang peranan penting dalam proses pembelajaran untuk mencapai tujuan pembelajaran yang efektif (Nana, 2008: 28).Belajar adalah suatu proses usaha yang dilakukan seseorang untuk memperoleh suatu perubahan tingkah laku yang baru secara keseluruhan, sebagai hasil pengalamannya sendiri dalam interaksi dengan lingkungannya Slameto (Muh. Khafid dan Suroso, 2007: 189).

Hasil belajar dapat diukur dari tinggi rendahnya kemampuan belajarnya seseorang yang ditunjukkan oleh adanya perilaku sebagai hasil pengalaman (Reigelutin (Ahiri 2008: 2)). Menurut Usman dan Setiawati (2005: 4) mengatakan bahwa belajar adalah perubahan tingkah laku pada diri individu berkat adanya interaksi antara individu dengan individu, dalam individu dan lingkungannya, sehingga mereka lebih mampu berinteraksi dengan lingkungannya. Selanjutnya menurut Sardiman (2007: 36) menjelaskan bahwa dalam arti luas, belajar dapat diartikan sebagai kegiatan psikologi fisik menuju kelompok perkembangan pribadi seutuhnya. Kemudian dalam arti sempit, belajar merupakan kegiatan menuju terbentuknya kepribadian seutuhnya.

Pembelajaran yang menggunakan model kooperatif dapat memiliki ciri-ciri sebagai berikut: (a) siswa bekerja dalam kelompok secara kooperatif untuk menuntaskan materi belajarnya, (b) kelompok dibentuk dari siswa yang memiliki kemampuan tinggi, sedang dan rendah, (c) bilamana mungkin, anggota kelompok berasal dari ras, budaya, suku, jenis kelamin berbeda-beda dan (d) penghargaan lebih berorientasi kelompok ketimbang individu. Lingkungan belajar untuk pembelajaran kooperatif dicirikan oleh proses demokrasi dan peran aktif siswa dalam menentukan apa yang harus dipelajari dan bagaimana mempelajarinya. Guru menerapkan struktur pembentukan kelompok dan mendefinisikan semua prosedur, namun siswa diberi kebebasan mengendalikan dari waktu ke waktu dalam kelompoknya (Ibrahim, dkk, 2002: 7).

Tujuan pembelajaran kooperatif adalah untuk membangkitkan interaksi yang efektif di antara anggota kelompok melalui diskusi. Dalam hal ini sebagian besar aktivitas pembelajaran berpusat pada siswa, yakni mempelajari materi pelajaran. Tujuan lain dari pembelajaran kooperatif adalah untuk mengajarkan kepada siswa keterampilan sosial atau kerja sama. Dalam pembelajaran kooperatif tidak hanya mempelajari keterampilan khusus yaitu keterampilan kooperatif. Keterampilan kooperatif ini berfungsi untuk melancarkan hubungan kerja dan tugas-tugas. Sedangkan peranan tugas dilakukan dengan membagi tugas antara anggota kelompok selama kegiatan (Ismail, 2004: 20).

Model pembelajaran kooperatif tipe STAD (Student Team Achievement Division) merupakan salah satu tipe pembelajaran kooperatif yang menekankan struktur-struktur khusus yang dirancang untuk mempengaruhi pola-pola interaksi siswa dan memiliki tujuan untuk meningkatkan penguasaan materi pelajaran. Student Teams-Achievement Divisions (STAD) dikembangkan oleh Robert E. Slavin dan rekan-rekan sejawatnya di Johns Hopkins University dan merupakan pendekatan cooperatif learning yang paling sederhana dan paling mudah dipahami.

STAD merupakan metode pembelajaran yang cocok diterapkan dalam kelas yang memiliki karakteristik yang heterogen, baik dalam kemampuan akademis, jenis kelamin, suku, dan lain-lain. Dalam pembelajaran kooperatif metode STAD ini tanggung jawab siswa terhadap proses belajar lebih besar karena siswa lebih banyak bekerja dari pada sekedar mendengarkan informasi, sehingga model pembelajaran ini dapat melatih tanggung jawab siswa terhadap proses belajarnya. Seperti dalam kebanyakan model pembelajaran kooperatif, STAD bekerja berdasarkan prinsip siswa bekerja bersama-sama untuk belajar dan bertanggung jawab terhadap belajar teman-temannya dalam tim dan juga dirinya sendiri (Huda, 2011: 115).

Model pembelajaran kooperatif tipe STAD adalah salah satu alternatif metode pembelajaran yang mampu memberikan hasil kedua aspek yang diharapkan untuk mencapai 
tujuan tersebut. Pendekatan kooperatif pada dasarnya merupakan metode mengajar yang melibatkan siswa dalam kelompok. Siswa yang dibentuk dalam kelompok kecil untuk mencapai tujuan dengan ciri-ciri tertentu antara lain seperti saling ketergantungan positif, interaksi langsung antar siswa dan pertanggung jawaban individu. Pendekatan kooperatif model STAD digunakan untuk mengembangkan siswa dalam hal keaktifan dan kemandirian, sikap tanggung jawab dalam belajar dan berani mengemukakan pendapat, berfikir secara kritis dan teratur, disiplin serta keberanian mengambil keputusan. Proses pembelajaran dengan strategi pembelajaran kooperatif tipe STAD dimulai dengan membagi siswa menjadi kelompokkelompok kecil (4-5 siswa perkelompok). Setiap kelompok ditempatkan di dalam kelas sedemikian rupa sehingga antara anggota kelompok dapat belajar dan berdiskusi dengan baik tanpa mengganggu kelompok lainnya. Guru membagi materi pelajaran, baik berupa lembar kerja siswa, buku dan penugasan. Selanjutnya guru menjelaskan tujuan belajar yang ingin dicapai dan memberikan pengarahan materi yang harus dipelajari dan permasalahanpermasalahan yang harus diselesaikan. Siswa secara sendiri-sendiri mempelajari materi pelajaran, dan jika ada kesulitan mereka saling berdiskusi dengan teman-temannya dalam kelompok. Untuk penguasaan materi pelajaran atau penyelesain tugas-tugas yang telah ditentukan, setiap siswa dalam kelompok ikut bertanggungjawab secara bersama-sama (Nur, 2009: 6).

Pembelajaran yang menggunakan model kooperatif tipe STAD memiliki ciri sebagai berikut:

a. Siswa bekerja dalam kelompok secara kooperatif.

b. Kelompok dibentuk dari siswa yang memiliki kemampuan tinggi, sedang dan rendah dan beranggotakan $4-5$ orang.

c. Bilamana memungkinkan, anggota kelompok berasal dari ras, budaya, suku dan jenis kelamin berbeda-beda.

d. Penghargaan lebih berorientasi kelompok ketimbang individu.

Terdapat enam langkah utama (sintaks) dalam melaksanakan model pembelajaran kooperatif tipe STAD. Enam langkah utama dalam pembelajaran kooperatif tipe STAD ini dapat diuraikan pada tabel berikut:

Tabel 1.

Fase-fase Pembelajaran Kooperatif Tipe STAD

\begin{tabular}{|c|c|}
\hline Fase-fase & Tingkah Laku Guru \\
\hline $\begin{array}{l}\text { Fase } 1 \\
\text { Penyampaian tujuan dan } \\
\text { memotivasi siswa }\end{array}$ & $\begin{array}{l}\text { Guru menyampaikan semua tujuan yang } \\
\text { dicapai pada pelajaran tersebut dan memotivasi } \\
\text { siswa belajar. }\end{array}$ \\
\hline $\begin{array}{l}\text { Fase } 2 \\
\text { Menyampaikan informasi }\end{array}$ & $\begin{array}{l}\text { Guru menyajikan informasi kepada siswa } \\
\text { dengan jalan demonstrasi atau lewat bahan } \\
\text { bacaan. }\end{array}$ \\
\hline $\begin{array}{l}\text { Fase } 3 \\
\text { Mengorganisasikan siswa } \\
\text { kedalam kelompok belajar }\end{array}$ & $\begin{array}{l}\text { Sebelum pembelajaran berlangsung, } \\
\text { Guru menjelaskan kepada siswa bagaimana } \\
\text { cara membentuk kelompok agar melakukan } \\
\text { transisi secara efisien }\end{array}$ \\
\hline $\begin{array}{l}\text { Fase } 4 \\
\text { Membimbing kelompok } \\
\text { bekerja dan belajar }\end{array}$ & $\begin{array}{l}\text { Guru membimbing kelompok-kelompok belajar } \\
\text { pada saat mereka mengerjakan tugas mereka. }\end{array}$ \\
\hline $\begin{array}{l}\text { Fase } 5 \\
\text { Evaluasi }\end{array}$ & $\begin{array}{l}\text { Guru mengevaluasi hasil belajar tentang materi } \\
\text { yang telah dipelajari dimana masing-masing } \\
\text { kelompok mempresentasikan hasil karyanya. }\end{array}$ \\
\hline $\begin{array}{l}\text { Fase } 6 \\
\text { Memberikan penghargaan }\end{array}$ & $\begin{array}{l}\text { Guru memberi apresiasi atau pujian sebagai } \\
\text { penghargaan pada upaya hasil belajar individu } \\
\text { dan kelompok }\end{array}$ \\
\hline
\end{tabular}

(Ibrahim, 2002: 10) 
Langkah-langkah memberi penghargaan kelompok, yaitu

1. Menentukan nilai dasar (awal) masingmasing siswa. Nilai dasar dapat berupa tes awal atau menggunakan nilai ulangan sebelumnya.

2. Menentukan nilai tes/kuis yang telah dilaksanakan setelah siswa bekerja kelompok, misal nilai kuis I, kuis II, kuis III kepada setiap siswa yang disebut nilai kuis terkini.

3. Menghitung skor individu

Untuk menghitung perkembangan skor individu, dapat dilihat pada tabel berikut.

Tabel 2.

Penghitungan Perkembangan Skor Individu

\begin{tabular}{|l|c|}
\hline \multicolumn{1}{|c|}{ Nilai Tes } & Skor Perkembangan \\
\hline $\begin{array}{l}\text { Nilai tes terkini turun lebih dari 10 poin di bawah } \\
\text { nilai awal }\end{array}$ & 0 \\
\hline $\begin{array}{l}\text { Nilai tes terkini turun 1 sampai 10 poin di bawah } \\
\text { nilai awal }\end{array}$ & 10 \\
\hline $\begin{array}{l}\text { Nilai tes terkini sama dengan nilai awal sampai } \\
\text { dengan 10 poin di atas nilai awal }\end{array}$ & 20 \\
\hline $\begin{array}{l}\text { Nilai tes terkini lebih dari 10 poin di atas nilai } \\
\text { awal }\end{array}$ & 30 \\
\hline
\end{tabular}

Slavin (I Wayan Sadia, 2014: 91-92)

\section{Metode}

Penelitian ini dilaksanakan pada tanggal 15 November 2017 sampai 30 November 2017 semester I tahun ajaran 2017/2018 di kelas $\mathrm{VII}_{\mathrm{E}}$ SMP Negeri 1 Kabawo. Subjek penelitian ini adalah siswa kelas $\mathrm{VII}_{\mathrm{E}}$ SMP Negeri 1 Kabawo Semester I (ganjil) tahun ajaran 2017/2018 dengan jumlah siswa 25 orang. Penetapan kelas $\mathrm{VII}_{\mathrm{E}}$ didasarkan pada data ulangan harian siswa yang memiliki nilai rata-rata yang paling rendah.

Data nilai ulangan harian siswa kelas VII SMP Negeri 1 Kabawo dapat dilihat pada tabel 3. sebagai berikut:

Tabel 3.

Data Nilai Ulangan Harian Matematika Siswa Kelas VII SMPN 1 Kabawo

\begin{tabular}{|c|c|c|}
\hline No & Kelas & Nilai rata-rata \\
\hline 1 & $\mathrm{VII}_{\mathrm{A}}$ & 69,77 \\
\hline 2 & $\mathrm{VII}_{\mathrm{B}}$ & 69,96 \\
\hline 3 & $\mathrm{VII}_{\mathrm{C}}$ & 68,90 \\
\hline 4 & $\mathrm{VII}_{\mathrm{D}}$ & 70,45 \\
\hline 5 & $\mathrm{VII}_{\mathrm{E}}$ & 66,52 \\
\hline 6 & $\mathrm{VII}_{\mathrm{F}}$ & 68,45 \\
\hline 7 & $\mathrm{VII}_{\mathrm{G}}$ & 67,95 \\
\hline
\end{tabular}

Berdasarkan tabel di atas terlihat bahwa kelas $\mathrm{VII}_{\mathrm{E}}$ SMP Negeri 1 Kabawo memiliki nilai rata-rata yang paling rendah.

Faktor yang diteliti dalam penelitian ini adalah sebagai berikut:

1. Faktor siswa: untuk melihat hasil belajar siswa dari segi kognitif dalam mempelajari matematika khususnya pada materi persamaan dan pertidaksamaan linear satu variabel yang diajarkan pada saat penelitian dilaksanakan.

2. Faktor guru: untuk melihat bagaimana guru menerapkan model pembelajaran kooperatif tipe STAD pada materi persamaan dan pertidaksamaan linear satu variabel. 
Penelitian tindakan kelas ini direncanakan terdiri dari tiga siklus. Untuk mengetahui kemampuan awal siswa, maka sebelum pelaksanaan tindakan terlebih dahulu diberikan tes awal yang digunakan untuk pembagian kelompok. Tiap siklus terdiri dari 4 tahapan kegiatan, yaitu perencanaan, pelaksanaan tindakan, observasi dan evaluasi, refleksi. Jenis data yang diperoleh adalah data kuantitatif dan kualitatif. Data kuantitatif diproleh dari tes hasil belajar sedangkan data kualitatif diperoleh dari lembar observasi.

Penelitian ini merupakan penelitian tindakan kelas (Classsroom Action Research) dengan menyelidiki variabel penelitian yaitu hasil belajar matematika siswa dengan menggunakan model pembelajaran kooperatif tipe STAD. Data dalam penelititan ini dihimpun melalui observasi dan tes. Observasi dilakukan oleh teman sejawat sebagai observer dengan menggunakan lembar observasi. Penggunaan lembar observasi ini untuk melihat proses pelaksanaan pembelajaran yang dilaksanakan oleh guru ketika menggunakan model pembelajaran kooperatif tipe STAD pada mata pelajaran matematika. Sedangkan tes dimaksudkan untuk memperoleh data tentang hasil belajar matematika siswa. Tes dilaksanakan oleh guru pada akhir tindakan sampai mencapai indikator yang ditetapkan yaitu $80 \%$ secara klasikal siswa telah mencapai kriteria ketuntasan minimal (KKM) yang ditetapkan oleh sekolah yaitu 71 untuk mata pelajaran matematika (sumber: KKM mata pelajaran Matematika di SMPN 1 Kabawo). Data hasil belajar matematika diambil dengan menggunakan tes hasil belajar tiap siklus.

Teknik analisis data yang digunakan dalam penelitian ini berupa analisis deskriptif yang dimaksudkan untuk memberikan gambaran aktivitas pembelajaran dan hasil belajar matematika yang diajar dengan menggunakan model pembelajaran kooperatif tipe STAD melalui tes formatif siklus I, siklus II dan siklus III.

Adapun rumus yang digunakan yaitu sebagai berikut :

a. Seorang siswa dikatakan tuntas belajar secara individual jika siswa tersebut telah memperoleh nilai minimal 71 .

$$
\text { nilai akhir }=\frac{\text { skor perolehan siswa }}{\text { skor total }} \times 100 \%
$$

b. Untuk mengetahui persentase ketuntasan belajar secara klasikal, dengan rumus ;

$$
\text { persentase ketuntasan hasil belajar }=\frac{\text { jumlah siswa yang memperoleh nilai } \geq 71}{\text { jumlah siswa yang mengikuti tes }} \times 100 \%
$$

c. Untuk menghitung rata-rata skor nilai siswa, dengan menggunakan rumus

$$
\begin{array}{clll}
\text { nilai rata - rata }=\frac{\text { skor total yang diperoleh seluruh siswa }}{\text { jumlah siswa }} & \multicolumn{2}{c}{} \\
\text { Indikator keberhasilan dalam penelitian } & \text { pelajaran matematika di sekolah } & \text { SMP } \\
\text { ini terdiri dari indikator keterlaksanaan skenario } & \text { Negeri 1 Kabawo). } & &
\end{array}
$$
pembelajaran dan indikator peningkatan hasil belajar siswa. Adapun persentasi kedua dari indikator tersebut adalah sebagai berikut:

1. Pembelajaran dikatakan berhasil jika minimal $90 \%$ skenario pembelajaran terlaksana, baik yang dilakukan oleh guru maupun oleh siswa.

2. Hasil belajar matematika dikatakan meningkat apabila ketuntasan secara klasikal minimal $80 \%$ siswa yang telah mencapai nilai KKM yaitu 71, yang telah ditetapkan oleh sekolah untuk mata pelajaran matematika (sumber: KKM mata

\section{Hasil}

\section{Kegiatan Pendahuluan}

Sebelum kegiatan penelitian dilakukan, peneliti melakukan pertemuan awal dengan kepala sekolah SMP Negeri 1 Kabawo yaitu pada tanggal 8 November 2017, pertemuan ini bermaksud untuk menyampaikan tujuan dari peneliti yaitu mengadakan penelitian di SMPN 1 Kabawo. Kepala sekolah merespon dengan baik maksud peneliti, namun ada syarat yang harus peneliti lakukan sesuai permintaan kepala sekolah bahwa ketika selesai meneliti, peneliti 
harus memberikan kepada sekolah hasil dari penelitian yang telah dilakukan. Selanjutnya kepala sekolah mengarahkan peneliti berdiskusi langsung dengan guru matematika kelas $\mathrm{VII}_{\mathrm{E}}$, tujuannya adalah untuk mengetahui jadwal pelajaran untuk mata pelajaran matematika dan kesiapan guru dalam membantu peneliti. Data yang diperoleh dari hasil penelitian dari setiap siklus adalah data aktivitas, baik berupa aktivitas siswa maupun aktivitas guru dalam pembelajaran. Data tersebut dianalisis dengan menggunakan statistik deskriptif untuk memberikan gambaran aktivitas siswa, aktivitas guru dan hasil belajar siswa di kelas VIIE SMP Negeri 1 Kabawo dengan penerapan model pembelajaran kooperatif tipe Student Teams Achievement Division (STAD) yang berupa rerata dan persentase ketuntasan hasil belajar siswa.

Pada tanggal 15 November 2017 diadakan tes awal pada siswa kelas $\mathrm{VII}_{\mathrm{E}}$. Untuk mengetahui kemampuan awal siswa terhadap materi bentuk aljabar. Nilai tes awal dijadikan acuan untuk pembagian kelompok belajar matematika siswa kelas VII $_{\mathrm{E}}$ SMP Negeri 1 Kabawo setelah diterapkan model pembelajaran kooperatif tipe STAD. Soal-soal tes awal berupa materi yang berhubungan dengan pokok bahasan yang telah diajarkan dalam hal ini materi untuk soal tes awal adalah materi bentuk aljabar.

\section{Deskripsi Tindakan Siklus 1}

a. Perencanaan

Setelah ditetapkan dan disepakati untuk menerapkan model pembelajaran kooperatif tipe Student Teams Achievement Division (STAD) pada materi persamaan dan pertidaksamaan linear satu variabel, maka kegiatan selanjutnya ada beberapa hal yang diperlukan dan dipersiapkan oleh peneliti selama pelaksanaan tindakan. Dalam persiapan ini dilakukan dengan berkonsultasi antara peneliti dengan guru kelas $\mathrm{VII}_{\mathrm{E}}$ SMP Negeri 1 Kabawo (kolaborator) sebagai observer pada penelitian ini. Selanjutnya, peneliti melakukan hal-hal sebagai berikut:

1) Penentuan cakupan materi pembelajaran yang akan dilakukan pada tindakan siklus I.

2) Membuat skenario pembelajaran atau RPP pertemuan I dan pertemuan II.

3) Menyediakan perangkat pembelajaran seperti buku paket Matematika kelas VII, bahan ajar serta LKS.
4) Menyediakan instrumen tes hasil belajar berupa esay yang digunakan pada akhir siklus I.

5) Membuat lembar observasi aktivitas guru dan aktivitas siswa.

6) Membuat jurnal reflesksi diri.

b. Pelaksanaan Tindakan dan Observasi

Pelaksanaan kegiatan pembelajaran dengan menerapkan model pembelajaran kooperatif tipe Student Teams Achievement Division (STAD) pada materi persamaan dan pertidaksamaan linear satu variabel sesuai dengan RPP pada pertemuan I pada sub materi memahami konsep persamaan linear satu variabel dan RPP pada pertemuan II pada sub materi bentuk setara dan himpunan penyelesaian dari Persamaan Linear Satu Variabel.

Dalam kegiatan ini juga dilaksanakan observasi terhadap pelaksanaan tindakan dengan menggunakan lembar pengamatan pembelajaran STAD yang telah dirancang sebelumnya. Observasi dilakukan bersamaan dengan kegiatan pembelajaran untuk memantau optimalisasi penerapan model pembelajaran kooperatif tipe STAD yang dilakukan oleh observer yaitu guru kelas $\mathrm{VII}_{\mathrm{E}}$ dan untuk melihat aktivitas siswa selama kegiatan pembelajaran yang dilakukan oleh observer (teman sejawat).

Observasi terhadap guru meliputi mempersiapkan siswa untuk belajar, menyampaikan tujuan pembelajaran, memotivasi siswa, membagi siswa dalam 5 kelompok secara heterogen, menyiapkan bahan ajar serta LKS, membimbing siswa dalam mengerjakan LKS, mempersilahkan kepada masing-masing kelompok untuk mempresentasikan hasil kerja kelompok di depan kelas, dan membimbing siswa untuk menarik kesimpulan dari materi yang telah dipelajari. Hasil analisis observasi guru sesuai dengan lembar observasi pada siklus I skor yang dicapai oleh guru yang terlaksana sebanyak $76,19 \%$, sedangkan yang tidak terlaksana sebanyak $23,81 \%$.

Observasi terhadap siswa meliputi keterlibatan siswa dalam kegiatan pembelajaran, keterlibatan siswa dalam menanggapi penjelasan guru, keaktifan siswa dalam kelompok baik dalam belajar maupun dalam mengerjalan soalsoal, keaktifan siswa dalam megerjakan LKS, keaktifan siswa dalam mempersentasekan hasil kerja kelompoknya, keterlibatan siswa dalam menyimpulkan materi pembelajaran, dan 
penguasan terhadap materi yang diberikan. Skor observasi siswa yang dicapai berdasarkan lembar observasi pada siklus I yang terlaksana sebanyak $71,42 \%$, sedangkan yang tidak terlaksana sebanyak $28,58 \%$.

c. Evaluasi

Setelah pelaksanaan tindakan siklus I selama 2 kali pertemuan, maka kegiatan selanjutnya dilakukan evaluasi atau tes hasil belajar. Hal ini dilakukan untuk mengukur sejauh mana kemampuan kognitif siswa setelah menerapkan model pembelajaran kooperatif tipe STAD dalam proses pembelajaran. Evaluasi dilakukan secara individu, karena dengan cara ini peneliti bisa melihat kemampuan kognitif siswa atas materi yang telah diajarkan. Dalam pencapaian hasil belajar siswa dikelompokkan dalam dua kategori yaitu kategori tuntas dan kategori belum tuntas

Kegiatan yang dilakukan oleh peneliti pada siklus 1 meliputi perencanaan, pelaksanaan tindakan dan observasi, evaluasi dan refleksi.
Ketuntasan hasil belajar siswa pada siklus I menunjukkan bahwa terjadi peningkatan jika dibandingkan dengan hasil tes awal yaitu sdari sebanyak 25 siswa yang mengikuti tes hanya 10 siswa memperoleh nilai $\geq 71$ atau dengan persentase ketuntasan $40 \%$ siswa yang mencapai KKM pada tes awal, sedangkan 15 siswa memperoleh nilai dibawah 71 atau dengan persentase $60 \%$, dengan rata-rata 71,60 dan meningkat menjadi dari sebanyak 25 yang mengikuti tes hanya 16 siswa yang memperoleh nilai $\geq 71$ atau dengan persentase $64 \%$ siswa mencapai KKM, sedangkan 9 siswa yang memperoleh nilai di bawah 71 atau dengan persentase $36 \%$, dengan rata-rata nilai hasil belajar siswa 76,84 . Kenyataan tersebut belum mencapai indikator kinerja dari segi hasil yaitu $80 \%$ siswa mencapai nilai $\geq 71$. Hasil analisis ketuntasan belajar siswa pada penelitian hasil belajar secara klasikal dapat dilihat pada tabel berikut ini:

Tabel 4.

Analisis Ketuntasan Hasil Belajar Siswa Siklus I

\begin{tabular}{|c|c|c|c|c|}
\hline No. & Ketuntasan & Skor & Jumlah siswa & Persentase (\%) \\
\hline 1 & Belum tuntas & $0-70$ & 9 & $36 \%$ \\
\hline 2 & Tuntas & $71-100$ & 16 & $64 \%$ \\
\hline \multicolumn{2}{|c|}{ Total } & 25 & $100 \%$ \\
\hline
\end{tabular}

Tabel 4. menunjukkan bahwa persentase ketuntasan hasil belajar siswa pada siklus I mencapai 64\% yang mencapai KKM dan 36\% belum mencapai KKM. Dalam hal ini belum mencapai target peneliti yaitu ketuntasan $80 \%$. Hal ini disebabkan karena selama dalam proses pembelajaran pada siklus I, tampak bahwa siswa masih cenderung pasif dalam menerima pembelajaran, kurang membaca buku paket maupun bahan ajar, dan kurang berdiskusi sesama siswa dalam kelompoknya. Dari beberapa hal tersebut diduga berpengaruh pada hasil belajar matematika siswa khususnya bagi siswa yang belum mencapai KKM.

\section{d. Refleksi}

Refleksi merupakan proses atau tahap dalam penelitian tindakan kelas dimana bertujuan untuk memperbaiki kesalahan yang terjadi pada setiap akhir pembelajaran. Berdasarkan hasil observasi dan evaluasi pada pelaksanaan tindakan siklus I baik pertemuan I dan pertemuan II masih jauh dari harapan yang telah ditetapkan sebelumnya. Berdasarkan hasil diskusi antara peneliti dengan observer (guru kelas), dimana terlihat beberapa kekurangan saat proses pembelajaran berlangsung baik itu dilakukan oleh guru maupun siswa.

\section{Deskripsi Tindakan Siklus II}

Kegiatan yang dilakukan oleh peneliti pada siklus II sama dengan tindakan yang dilakukan pada siklus I meliputi perencanaan, pelaksanaan tindakan dan observasi, evaluasi dan refleksi. Masing-masing kegiatan ini diuraikan sebagai berikut:

\section{a. Perencanaan}

Berdasarkan hasil observasi, evaluasi, dan refleksi pada siklus I, maka peneliti bersama observer kembali merencanakan siklus II dengan harapan kelemahan dan kekurangan pada pelaksanaan pembelajaran siklus I dapat diperbaiki, sehingga tindakan pada siklus II mengalami perubahan dengan baik. Dalam perencanaan tindakan ini peneliti kembali 
menyiapkan hal-hal yang akan dilakukan dalam pembelajaran seperti :

1. Penentuan cakupan materi pembelajaran yang akan dilakukan pada tindakan siklus II.

2. Membuat skenario pembelajaran atau RPP pertemuan I dan pertemuan II.

3. Menyediakan perangkat pembelajaran seperti buku paket Matematika kelas VII, bahan ajar serta LKS.

4. Menyediakan instrumen tes hasil belajar berupa esay tes yang digunakan pada akhir siklus II.

5. Membuat lembar observasi aktivitas guru dan aktivitas siswa.

6. Membuat jurnal refleksi diri.

b. Pelaksanaan Tindakan dan Observasi

Pelaksanaan kegiatan pembelajaran dengan menerapkan model pembelajaran kooperatif tipe STAD pada materi persamaan dan pertidaksamaan linear satu variabel sesuai dengan RPP pada pertemuan I pada sub materi konsep pertidaksamaan linear satu variabel dan RPP pada pertemuan II pada sub materi bentuk setara dan himpunan penyelesaian dari pertidaksamaan linear satu variabel.

Dalam kegiatan ini juga dilaksanakan observasi terhadap pelaksanaan tindakan dengan menggunakan lembar pengamatan pembelajaran kooperatif tipe STAD yang telah dirancang sebelumnya. Observasi dilakukan bersamaan dengan kegiatan pembelajaran untuk memantau optimalisasi penerapan model pembelajaran kooperatif tipe STAD yang dilakukan oleh observer yaitu guru kelas $\mathrm{VII}_{\mathrm{E}}$ dan untuk melihat aktivitas siswa selama kegiatan pembelajaran yang dilakukan oleh observer (teman sejawat). Observasi terhadap guru meliputi mempersiapkan siswa untuk belajar, menyampaikan tujuan pembelajaran, apersepsi dan memotivasi siswa, membagi siswa dalam 5 kelompok secara heterogen, menyiapkan LKS serta bahan ajar, membimbing serta mengawasi siswa dalam mengerjakan LKS, mempersilahkan kepada masing-masing kelompok untuk mempresentasikan hasil kerja kelompok di depan kelas, dan mengevaluasi hasil diskusi. Hasil analisis observasi guru pada siklus II skor yang dicapai oleh guru yang terlaksana sebanyak $85,71 \%$, sedangkan yang tidak terlaksana mencapai $14,29 \%$.

Observasi terhadap siswa meliputi keterlibatan siswa dalam kegiatan pembelajaran, keterlibatan siswa dalam menanggapi penjelasan guru, keaktifan siswa dalam kelompok baik dalam balajar maupun dalam mengerjalan soalsoal LKS, keaktifan siswa dalam mempersentasekan hasil kerja kelompoknya, keterlibatan siswa dalam menyimpulkan materi pembelajaran, dan penguasan terhadap materi yang diberikan.

Adapun skor observasi siswa yang dicapai berdasarkan lembar observasi pada siklus II yang terlaksana sebanyak $85,71 \%$, sedangkan yang tidak terlaksana sebanyak $14,29 \%$.

c. Evaluasi

Setelah pelaksanaan tindakan siklus II selama 2 kali pertemuan, maka kegiatan selanjutnya dilakukan evaluasi atau tes hasil seperti yang ada pada lampiran 54. Hal ini dilakukan untuk mengukur sejauh mana kemampuan kognitif siswa setelah menerapkan model pembelajaran kooperatif tipe STAD dalam proses pembelajaran. Evaluasi dilakukan secara individu, karena dengan cara ini peneliti bisa melihat kemampuan kognitif siswa atas materi yang telah diajarkan. Dalam pencapaian hasil belajar siswa dikelompokkan dalam dua kategori yaitu kategori tuntas dan kategori belum tuntas.

Kegiatan yang dilakukan oleh peneliti pada siklus II sama dengan tindakan yang dilakukan pada siklus I meliputi perencanaan, pelaksanaan tindakan dan observasi, evaluasi dan refleksi. Ketuntasan hasil belajar siswa pada siklus II menunjukan hasil belajar seluruh siswa sebanyak 25 yang mengikuti tes hanya 19 siswa yang memperoleh nilai $\geq 71$ atau dengan persentase $76 \%$ siswa mencapai KKM, sedangkan 6 siswa yang memperoleh nilai di bawah 71 atau dengan persentase $26 \%$, dengan rata-rata nilai hasil belajar siswa 77,48. Kenyataan tersebut belum mencapai indikator kinerja dari segi hasil yaitu $80 \%$ siswa mencapai nilai $\geq 71$. Hasil analisis ketuntasan belajar siswa pada penelitian hasil belajar secara klasikal dapat dilihat pada tabel berikut ini: 
Tabel 5.

Analisis Ketuntasan Hasil Belajar Siswa Siklus II

\begin{tabular}{|c|c|c|c|c|}
\hline No. & Ketuntasan & Skor & Jumlah siswa & Persentase (\%) \\
\hline 1 & Belum tuntas & $0-70$ & 6 & $24 \%$ \\
\hline 2 & Tuntas & $71-100$ & 19 & $76 \%$ \\
\hline \multicolumn{2}{|c|}{ Total } & 25 & $100 \%$ \\
\hline
\end{tabular}

Tabel 5. menunjukkan bahwa persentase ketuntasan hasil belajar siswa pada siklus II mencapai $76 \%$ yang mencapai KKM dan $24 \%$ belum mencapai KKM. Dalam hal ini belum mencapai target peneliti yaitu indikator keberhasilan $80 \%$. Hal ini disebabkan karena selama proses pembelajaran di kelas pada siklus II, tampak bahwa siswa banyak bermain dalam proses pembelajaran, sehingga membuat teman yang lain terganggu. Dari hal ini diduga berpengaruh pada hasil belajar matematika siswa khususnya bagi siswa yang belum tuntas hasil belajarnya.

\section{d. Refleksi}

Refleksi merupakan proses atau tahap dalam penelitian tindakan kelas dimana bertujuan untuk memperbaiki kesalahan yang terjadi pada setiap akhir pembelajaran. Berdasarkan hasil observasi dan evaluasi pada pelaksanaan tindakan siklus II baik pertemuan I dan pertemuan II sesuai rencana yang telah ditetapkan sebelumnya, hal ini berdasarkan hasil diskusi antara peneliti dengan observer (guru kelas) dimana terlihat bahwa pembelajaran dengan menerapkan model pembelajaran kooperatif tipe STAD sudah dapat dilaksanakan hampir semua tahapan kegiatan dalam skenario pembelajaran pada siklus II baik yang dilakukan oleh guru maupun oleh siswa namun belum mendapatkan hasil yang lebih baik. Berdasarkan hasil observasi dan evaluasi pelaksanaan tindakan siklus II, hal yang masih perlu diperhatikan adalah bimbingan terhadap siswa yang mengalami kesulitan dalam mengerjakan latihan perlu ditingkatkan. Kelemahankelemahan dan kekurangan-kekurangan yang terjadi pada tindakan siklus II akan diperbaiki pada pelaksanaan tindakan siklus III.

\section{Deskripsi Tindakan Siklus III}

Kegiatan yang dilakukan oleh peneliti pada siklus III sama dengan tindakan yang dilakukan pada siklus I dan siklus II meliputi perencanaan, pelaksanaan tindakan dan observasi, evaluasi dan refleksi. Masing-masing kegiatan ini diuraikan sebagai berikut:

a. Perencanaan

Berdasarkan hasil observasi, evaluasi, dan refleksi pada siklus I dan siklus II, maka peneliti bersama observer kembali merencanakan siklus III dengan harapan kelemahan dan kekurangan pada pelaksanaan pembelajaran siklus I dan siklus II dapat diperbaiki, sehingga tindakan pada siklus III mengalami perubahan dengan baik. Dalam perencanaan tindakan ini peneliti kembali menyiapkan hal-hal yang akan dilakukan dalam pembelajaran seperti

1) Penentuan cakupan materi pembelajaran yang akan dilakukan pada tindakan siklus III.

2) Membuat skenario pembelajaran atau RPP pertemuan I dan pertemuan II.

3) Menyediakan perangkat pembelajaran seperti buku paket Matematika kelas VII, bahan ajar serta LKS.

4) Menyediakan instrumen tes hasil belajar berupa esay tes yang digunakan pada akhir siklus III.

5) Membuat lembar observasi aktivitas guru dan aktivitas siswa.

6) Membuat jurnal refleksi diri.

b. Pelaksanaan Tindakan dan Observasi

Pelaksanaan kegiatan pembelajaran dengan menerapkan model pembelajaran kooperatif tipe STAD pada materi persamaan dan pertidaksamaan linear satu variabel sesuai dengan RPP pada pertemuan I pada sub materi mengubah masalah kedalam matematika yang berbentuk persamaan dan pertidaksamaan linear satu variabel dan RPP pada pertemuan II pada sub materi menyelesaikan model matematika suatu masalah yang berkaitan dengan persamaan dan pertidaksamaan linear satu variabel.

Dalam kegiatan ini juga dilaksanakan observasi terhadap pelaksanaan tindakan dengan menggunakan lembar pengamatan pembelajaran kooperatif tipe STAD yang telah dirancang sebelumnya. Observasi dilakukan bersamaan dengan kegiatan pembelajaran untuk memantau 
optimalisasi penerapan model pembelajaran kooperatif tipe STAD yang dilakukan oleh observer yaitu guru kelas $\mathrm{VII}_{\mathrm{E}}$ dan untuk melihat aktivitas siswa selama kegiatan pembelajaran yang dilakukan oleh observer (teman sejawat). Observasi terhadap guru meliputi mempersiapkan siswa untuk belajar, menyampaikan tujuan pembelajaran, apersepsi dan memotivasi siswa, membagi siswa dalam 5 kelompok secara heterogen, menyiapkan LKS serta bahan ajar, membimbing serta mengawasi siswa dalam mengerjakan LKS, mempersilahkan kepada masing-masing kelompok untuk mempresentasikan hasil kerja kelompok di depan kelas, dan mengevaluasi hasil diskusi. Hasil analisis observasi guru pada siklus III skor yang dicapai oleh guru yang terlaksana sebanyak 95,23\%, sedangkan yang tidak terlaksana mencapai $4,77 \%$.

Observasi terhadap siswa meliputi keterlibatan siswa dalam kegiatan pembelajaran, keterlibatan siswa dalam menanggapi penjelasan guru, keaktifan siswa dalam kelompok baik dalam balajar maupun dalam mengerjalan soalsoal LKS, keaktifan siswa dalam mempersentasekan hasil kerja kelompoknya, keterlibatan siswa dalam menyimpulkan materi pembelajaran, dan penguasan terhadap materi yang diberikan. Adapun skor observasi siswa yang dicapai berdasarkan lembar observasi pada siklus III yang terlaksana sebanyak 85,71\%, sedangkan yang tidak terlaksana sebanyak $4,77 \%$.

c. Evaluasi

Setelah pelaksanaan tindakan siklus III selama 2 kali pertemuan, maka kegiatan selanjutnya dilakukan evaluasi atau tes hasil. Hal ini dilakukan untuk mengukur sejauh mana kemampuan kognitif siswa setelah menerapkan model pembelajaran kooperatif tipe STAD dalam proses pembelajaran. Evaluasi dilakukan secara individu, karena dengan cara ini peneliti bisa melihat kemampuan kognitif siswa atas materi yang telah diajarkan. Dalam pencapaian hasil belajar siswa dikelompokkan dalam dua kategori yaitu kategori tuntas dan kategori belum tuntas.

Ketuntasan hasil belajar siswa pada siklus III menunjukan hasil belajar seluruh siswa sebanyak 25 yang mengikuti tes hanya 23 siswa yang memperoleh nilai $\geq 71$ atau dengan persentase $92 \%$ siswa mencapai KKM, sedangkan 2 siswa yang memperoleh nilai di bawah 71 atau dengan persentase $8 \%$, dengan rata-rata nilai hasil belajar siswa 84,4. Kenyataan tersebut telah mencapai indikator kinerja dari segi hasil yaitu $80 \%$ siswa mencapai nilai $\geq 71$.

Hasil analisis ketuntasan belajar siswa pada penelitian hasil belajar secara klasikal dapat dilihat pada tabel berikut ini:

Tabel 6.

Analisis Ketuntasan Hasil Belajar Siswa Siklus III

\begin{tabular}{|l|l|c|c|c|}
\hline No. & Ketuntasan & Skor & Jumlah siswa & Persentase (\%) \\
\hline 1 & Belum tuntas & $0-70$ & 2 & $8 \%$ \\
\hline 2 & Tuntas Total & $71-100$ & 23 & $92 \%$ \\
\hline \multicolumn{2}{|c|}{} & 25 & $100 \%$ \\
\hline
\end{tabular}

Tabel 6. menunjukkan bahwa persentase ketuntasan hasil belajar siswa pada siklus III mencapai $92 \%$ yang mencapai KKM dan $8 \%$ belum mencapai KKM. Dalam hal ini telah mencapai target peneliti yaitu indikator keberhasilan 80\%. Hal ini disebabkan karena selama proses pembelajarn pada siklus III, siswa yang belum tuntas pembelajarannya tidak mengikuti proses pembelajaran pada salah satu pertemuan, sehingga siswa tersebut sulit mengerjakan soal-soal dalam tes siklus. Dari hal ini diduga berpengaruh pada hasil belajar matematika siswa yang belum mencapai KKM.

\section{d. Refleksi}

Refleksi merupakan proses atau tahap dalam penelitian tindakan kelas dimana bertujuan untuk memperbaiki kesalahan yang terjadi pada setiap akhir pembelajaran. Berdasarkan hasil observasi dan evaluasi pada pelaksanaan tindakan siklus III baik pertemuan I dan pertemuan II sesuai rencana yang telah ditetapkan sebelumnya, hal ini berdasarkan hasil diskusi antara peneliti dengan observer (guru kelas) dimana terlihat bahwa pembelajaran dengan menerapkan model pembelajaran kooperatif tipe STAD sudah mendapatkan hasil 
yang lebih baik, meskipun ada 2 orang siswa yang belum mencapai KKM.

Jika dilihat dari hasil tes pada evaluasi tindakan siklus III, yaitu telah mencapai 92\% siswa telah mencapai KKM dengan perolehan nilai $\geq 71$ dengan kata lain telah mencapai indikator keberhasilan yang ditetapkan oleh peneliti yaitu $80 \%$. Dengan demikian penelitian ini telah berhasil dilaksanakan sesuai dengan RPP dengan tiga siklus tindakan

Secara keseluruhan hasil penelitian yang telah dimulai dari tahap perencanaan, pelaksanaan tindakan, observasi dan evaluasi sampai tahapan refleksi yang terlaksana pada siklus I, siklus II, dan siklus III dapat ditunjukkan sebagai berikut:

Tabel 7.

Analisis Data Siklus I, Siklus II, dan Siklus III

\begin{tabular}{|c|c|c|c|c|}
\hline No. & Hasil Belajar Siswa & Tuntas & Belum Tuntas & Persentase Ketuntasan \\
\hline 1. & Siklus I & 16 & 9 & $64 \%$ \\
\hline 2. & Siklus II & 19 & 6 & $76 \%$ \\
\hline 3. & Siklus III & 23 & 2 & $92 \%$ \\
\hline
\end{tabular}

Tabel 7. menunjukkan bahwa persentase ketuntasan hasil belajar siswa mengalami peningkatan yakni pada siklus I dari 25 orang siswa hanya 16 orang siswa yang tuntas dengan persentase ketuntasan $64 \%$ yang mencapai KKM, pada siklus II mengalami peningkatan yaitu dari 25 orang siswa hanya 19 orang siswa yang tuntas dengan persentase ketuntasan $76 \%$ yang mencapai KKM, sedangkan pada siklus III juga mengalami peningkatan yaitu dari 25 orang siswa hanya 23 siswa yang tuntas dengan persentase ketuntasan 92\% telah mencapai standar KKM. Selanjutnya agar lebih jelas peningkatan hasil belajar siswa dari siklus I sampai dengan siklus III, dapat dilihat pada gambar berikut:

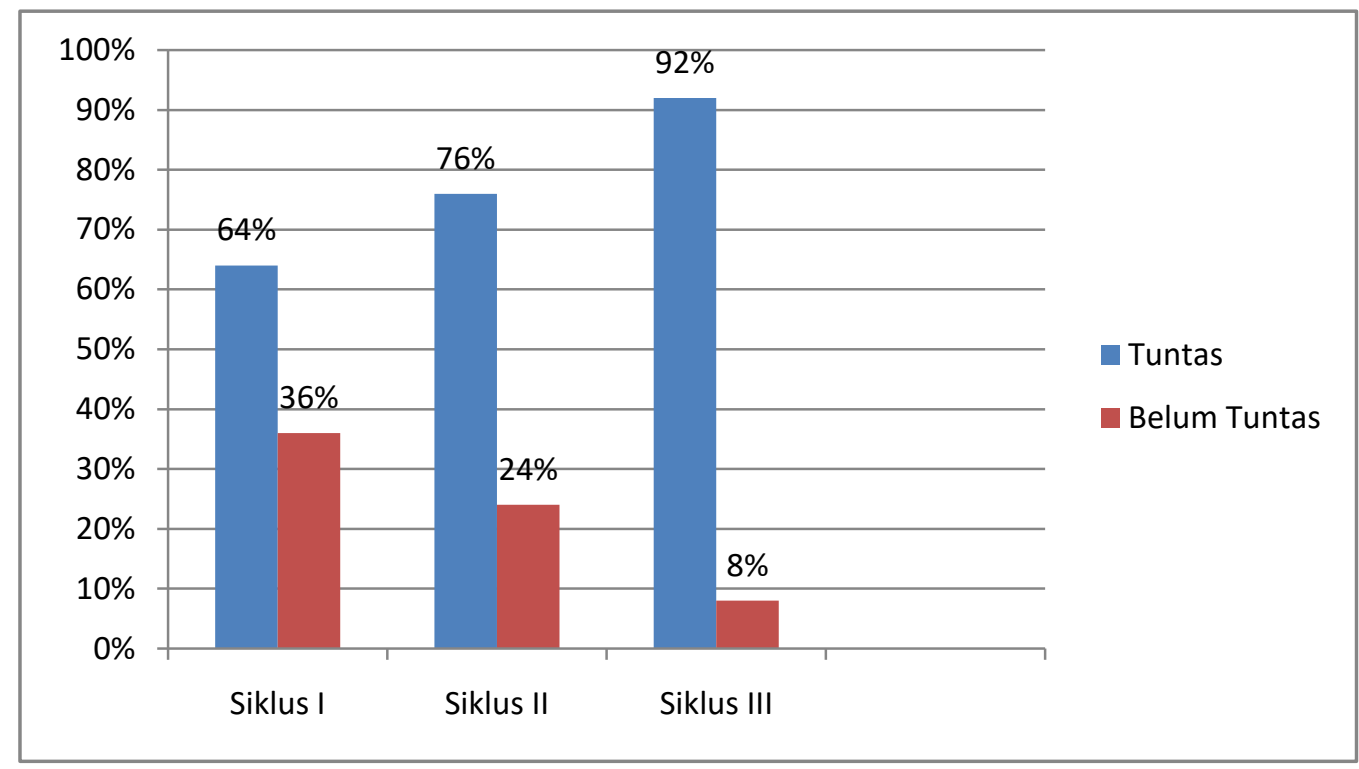

Gambar 1. Grafik Hasil Belajar Siswa pada Siklus I, Siklus II, dan Siklus III

Gambar 1. menunjukkan bahwa persentase ketuntasan hasil belajar siswa mengalami peningkatan dari siklus I sampai siklus III yakni pada siklus I persentase ketuntasan $64 \%$ yang mencapai KKM dengan persentase ketidaktuntasan $36 \%$, pada siklus II mengalami peningkatan dengan persentase ketuntasan $76 \%$ yang mencapai KKM dengan persentase ketidaktuntasan $24 \%$, sedangkan pada siklus III juga mengalami peningkatan dengan persentase 
ketuntasan $92 \%$ telah mencapai standar KKM dengan persentase ketidaktuntasannya $8 \%$.

\section{Pembahasan}

Menurut Kardiawarman (Paizaluddin dan Ermalinda, 2016: 6) mendefenisikan PTK sebagai suatu bentuk penelitian yang dilakukan pada sebuah kelas untuk mengetahui akibat tindakan yang diterapkan pada suatu subyek penelitian di kelas tersebut. Penelitian Tindakan Kelas (PTK) merupakan suatu penelitian yang dilakukan oleh guru/calon guru dalam kelasnya melalui refleksi diri yang bertujuan untuk memperbaiki proses pembelajaran sehingga hasil belajar siswa mengalami peningkatan. Pelaksanaan penelitian ini terdiri dari enam pertemuan yang dibagi menjadi tiga siklus.

Pada pelaksanaan pembelajaran tiap pertemuannya terdapat kegiatan yang mencerminkan model pembelajaran kooperatif tipe STAD yang terdiri dari 6 fase yaitu fase penyampaian tujuan dan memotivasi siswa, yaitu kegiatan guru menyampaikan semua tujuan yang dicapai pada pelajaran tersebut dan memotivasi siswa belajar, fase menyampaikan informasi, yaitu guru menyajikan informasi kepada siswa dengan jalan demonstrasi atau lewat bahan bacaan, fase mengorganisasikan siswa kedalam kelompok belajar, yaitu sebelum pembelajaran berlangsung, guru menjelaskan kepada siswa bagaimana cara membentuk kelompok, fase membimbing kelompok belajar dan bekerja, yaitu guru membimbing kelompokkelompok belajar pada saat mereka mengerjakan tugas mereka, fase evaluasi, yaitu guru mengevaluasi hasil belajar tentang materi yang telah dipelajari dimana masing-masing kelompok mempersentasikan hasil karyanya, dan fase memberikan penghargaan, yaitu guru memberi pujian sebagai penghargaan pada upaya hasil belajar individu dan kelompok.

Berdasarkan permasalahan pertama tentang bagaimana penerapan model pembelajaran kooperatif tipe STAD dalam pembelajaran matematika pada materi persamaan dan pertidaksamaan linear satu variabel. Untuk mengatasi rendahnya hasil belajar siswa pada siklus I, peneliti melakukan diskusi antara peneliti dengan observer dan disepakati adanya beberapa kelemahan guru dalam pengelolaan pembelajaran kooperatif tipe STAD di kelas adalah sebagai berikut: 1) guru belum menyampaikan indikator dan tujuan pembelajaran, 2) guru belum memberikan motivasi kepada siswa, sehingga siswa tidak serius dalam belajar, 3) guru belum memberikan bimbingan secara individu yang mengalami kesulitan, 4) guru belum memberikan penghargaan kepada kelompok yang memperoleh skor tertinggi.

Dari hasil refleksi tersebut kemudian ditentukan langkah-langkah perbaikan pada siklus II sebagai berikut: 1) selama pembelajaran berlangsung, guru harus menyampaikan indikator dan tujuan pembelajaran, 2) guru harus lebih banyak memberikan apersepsi dan motivasi kepada siswa untuk belajar, 3) guru harus memberikan bimbinga secara individual kepada siswa yang mengalami kesulitan, 4) guru harus memberikan penghargaan kepada kelompok yang mendapatkan skor tertinggi.

Berdasarkan hasil analisis dan refleksi tersebut, guru melakukan perbaikan-perbaikan untuk diterapkan pada siklus II serta memperbaharui cara menyampaikan materi pembelajaran dengan selalu melibatkan siswa dalam kegiatan pembelajaran, sehingga diharapkan dengan pembelajaran tersebut akan merangsang daya nalar siswa khususnya pada siswa kelas VII $\mathrm{VI}_{\mathrm{E}}$ SMP Negeri 1 Kabawo.

Berdasarkan tes hasil belajar siswa pada siklus I secara klasikal mencapai persentase ketuntasan yaitu $64 \%$ ketuntasan ini belum mencapai target peneliti yaitu persentase siswa belum mencapai $80 \%$. Sedangkan hasil evaluasi yang dilakukan pada siklus II, siswa yang yang mencapai persentase ketuntasan yaitu $76 \%$. Ini berarti mengalami peningkatan dibanding hasil evaluasi pada siklus I. Sedangkan siklus II ini belum mencapai indikator keberhasilan yang telah ditetapkan maka penelitian dilanjutkan kembali pada siklus berikutnya. Hal-hal yang harus diperbaiki pada siklus III adalah guru harus selalu membimbing siswa dalam mengerjakan soal-soal yang diberikan. Setelah siklus III dilakukan target ketuntasan siswa yaitu 92\% siswa telah tuntas dalam pembelajarannya. Hal ini peneliti dianggap telah berhasil mencapai targetnya atau mencapai indikator yang ditetapkan. Peningkatan yang terjadi juga dari tes awal, siklus I, siklus II maupun siklus III yang terjadi tidak lepas dari peran siswa, dimana siswa lebih aktif dan mau bekerja sama dengan kelompoknya. Karena indikator keberhasilan dalam penelitian telah tercapai, ini berarti 
hipotesis tindakan telah tercapai yaitu dengan menggunakan penerapan model pembelajaran kooperatif tipe Student Teams Achievement Division (STAD) dapat meningkatkan hasil belajar matematika siswa kelas $\mathrm{VII}_{\mathrm{E}} \mathrm{SMP}$ Negeri 1 Kabawo.

\section{Simpulan dan Saran}

\section{Simpulan}

Berdasarkan hasil atau temuan dalam penelitian ini dapat ditarik kesimpulan bahwa dengan menerapan model pembelajaran kooperatif tipe Student Teams Achievement Division (STAD) dapat meningkatkan hasil belajar matematika siswa kelas $\mathrm{VII}_{\mathrm{E}}$ SMP Negeri 1 Kabawo yakni pada siklus I dari 25 orang siswa hanya 16 orang siswa yang tuntas dengan persentase ketuntasan $64 \%$ dengan rata-rata 76,84 yang mencapai KKM, pada siklus II mengalami peningkatan yaitu dari 25 orang siswa hanya 19 orang siswa yang tuntas dengan persentase ketuntasan $76 \%$ dengan rata-rata 77,48 yang mencapai KKM, sedangkan pada siklus III juga mengalami peningkatan yaitu dari 25 orang siswa hanya 23 siswa yang tuntas dengan persentase ketuntasan $92 \%$ dengan ratarata 84,4 telah mencapai standar KKM.

\section{Saran}

Berdasarkan kesimpulan di atas, maka peneliti menyarankan hal-hal sebagai berikut:

1. Bagi Sekolah, khususnya SMP Negeri 1 Kabawo dapat mencoba menggunakan model pembelajaran kooperatif tipe STAD pada pembelajaran matematika sebagai inovasi pembelajaran untuk mengatasi banyaknya siswa yang pasif dalam pembelajaran.

2. Bagi guru mata pelajaran matematika yang sulit membangun dan mengembangkan kemampuan kognitif siswa diharapkan dapat menerapkan model pembelajaran kooperatif tipe STAD sebagai alternatif tindakan yang efektif dan efisien dalam upaya peningkatan hasil belajar matematika siswa.

\section{Daftar Pustaka}

Ahiri, Jafar. (2008). Faktor-faktor Yang Mempengaruhi Hasil Belajar. Unhalu: Kendari.

Depdiknas. (2009). Panduan Umum Pengembangan Silabus (Revisi). Jakarta: Ditjen Manajemen Pendidikan Dasar Dan Menengah Direktorat Pembinaan Sekolah Menengah Pertama.

Fitri Rahma dkk. (2014). Penerapan Strategi The Firing Line Pada Pembelajaran Matematika Siswa Kelas XI IPS SMA Negeri 1 Batipuh. Jurnal Pendidikan Matematika. Volume 3 No. 1, hal. 1819

Huda, Miftahul. (2011). Cooperative Learning. Yogyakarta: Pustaka Pelajar.

Ibrahim, M. (2002). Pembelajaran Kooperatif. Surabaya: University Press.

Ismail. (2004). Model-model Pembelajaran. Jakarta: Depdiknas.

Khafid Muhammad dan Suroso. (2007). Pengaruh Disiplin Belajar dan Lingkungan Keluarga terhadap Hasil Belajar Ekonomi. Jurnal Pendidikan. Volume 2 No. 2, hal 189.

Nana Sudjana. (2008). Dasar-dasar Proses Belajar Mengajar. Bandung : Sinar Baru Algensindo.

Nur, M. (2009). Pembelajaran Kooperatif. Surabaya: IKIP Surabaya.

Paizaluddin dan Ermalinda. (2016). Penelitian Tindakan Kelas. Bandung: Alfabeta. 